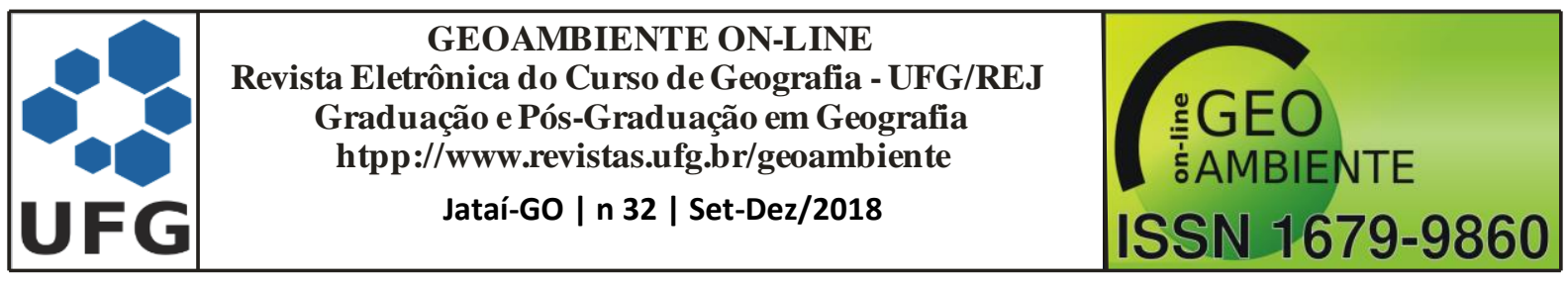

\title{
PROPOSTA DE ZONEAMENTO GEOAMBIENTAL DO MUNICÍPIO DE CURRAIS NOVOS/RN - BRASIL
}

\author{
Antônia Vilaneide Lopes Costa de Oliveira $^{1}$ Luiz Antonio Cestaro ${ }^{2}$
}

(1 - Universidade Federal do Rio Grande do Norte, Doutoranda em Geografia, vilaneide_oliveira@yahoo.com.br, 2 - Universidade Federal do Rio Grande do Norte, Professor do Departamento de Geografia, lacestaro@cchla.ufrn.br)

Resumo: O zoneamento geoambiental se configura em um instrumento de planejamento e ordenamento do território baseado no estudo das paisagens. Desse modo, embasado na abordagem do Geossistema, este trabalho teve o objetivo principal de propor um zoneamento geoambiental para o município de Currais Novos/RN. Para tanto, foi realizada revisão bibliográfica, compilação de dados, mapas e produtos de sensoriamento remoto, trabalho de campo, produção de mapas temáticos em meio digital (formato shapefile) e integração de dados cartográficos. Assim, foram identificados cinco sistemas geoambientais, a saber: Planalto da Borborema, Planalto Residual, Chapada da Serra de Santana, Vale fluvial Semiárido e Vale Lagunar, a partir desses, identificou-se dez subsistemas geoambientais, são eles: Planalto da Borborema Encosta Oriental, Planalto da Borborema Encosta Ocidental, Maciços Isolados do Planalto da Borborema, Cristas Residuais, Maciços Residuais, Escarpa Erosiva da Chapada, Chapada de Topo Plano, Planície de Inundação Fluvial, Rio Temporário do Semiárido e Lago Artificial ou Açude.

Palavras-Chave: Zoneamento geoambiental, Planejamento ambiental, Sistemas geoambientais.

\section{GEOENVIRONMENTAL ZONING OF THE CURRAIS NOVOS/RN - BRAZIL}

Abstract: The geoenvironmental zoning serves as an instrument for the planning and ordering of the territory based on the landscape analysis. Therefore based in the Geosystemic Theory this work has a main objective to propose a geoenvironmental zoning for the Currais Novos Municipality in RN. The process included a bibliographic study, the gathering of information, mapping and remote sensoring, fieldwork, the production of thematic maps in

\footnotetext{
Artigo recebido para publicação em 20 de Novembro de 2017

Artigo aprovado para publicação em 18 de Novembro de 2018
} 


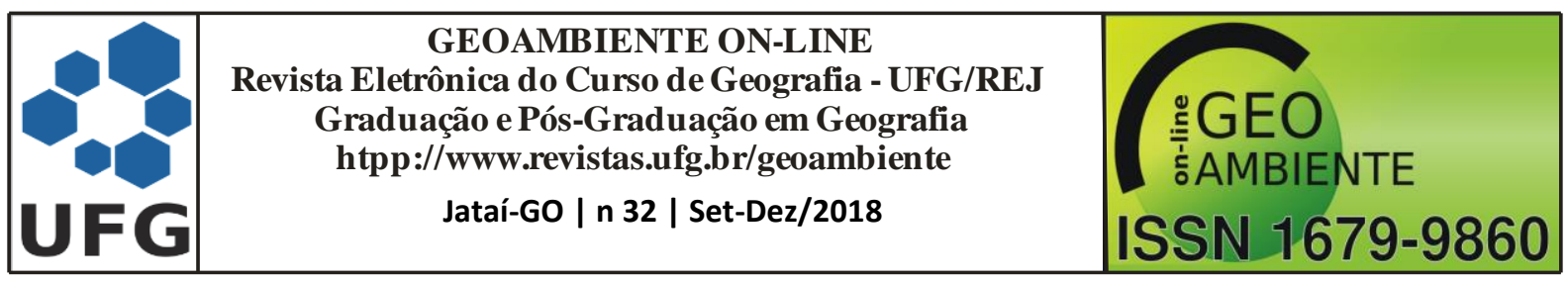

digital form, using Shapefile with digital overlay. There were identified five geoenvironmental systems: Borborema Plateau, Residual Plateau, Chapada da Serra de Santana, Semiarid River Valley and Lagoon Valley and ten geoenvironmental subsystems: Borborema Plateau Western Slope, Isolated Massif of the Borborema Plateau, Residual Crest, Residual Massif, Erosional Scarp of the Chapada, Flat Top Plateau, Fluvial Plains, Temporary River of the Semiarid and Ornamental Water or Sluice.

Keywords: geoenvironmental zoning, planning of the territory, geoenvironmental systems.

\section{PROPUESTA DE ZONIFICACIÓN GEOAMBIENTAL DEL MUNICIPIO DE CURRAIS NOVOS/RN - BRASIL}

Resumen: La zonificación geoambiental se configura en un instrumento de planificación y ordenación del territorio basado en el estudio de los paisajes. De ese modo, respaldado en la Teoría de Geosistema, este trabajo tuvo el objetivo principal de proponer una zonificación geoambiental para el municipio de Currais Novos - RN. Se realizó una revisión bibliográfica, compilación de datos, mapas y productos de imagen de satélite, trabajo de campo, producción de mapas temáticos en medio digital (shapefile) e integración de datos cartográficos.Así, fueron identificados cinco sistemas geoambientales, Planalto da Borborema,Planalto Residual, Chapada da Serra de Santana, Vale fluvial Semiárido y Vale Lagunar y diez subsistemas geoambientales, Planalto da Borborema Vertiente Oriental, Planalto da Borborema Vertiente Occidental, Macizos Aislados del Planalto da Borborema, Crestas Residuales, Macizos Residuales, Escarpe Erosivo de la Chapada, Chapada de Topo Plano, Planicie de Inundación Fluvial, Rio Temporario del Semiárido y Lago Artificial o Azud.

Palabras clave:Zonificación geoambiental, Planificación ambiental, Sistemas geoambientales.

\section{Introdução}

A evolução do pensamento geográfico permitiu definir a paisagem como a representação espacial de uma unidade geoambiental de complexa integração de elementos físico-naturais e humanos, que pode ser analisada através de métodos e técnicas, a favor do planejamento ambiental territorial. A paisagem é, portanto, o conjunto heterogêneo de formas naturais e artificiais formado por frações de ambas (SANTOS, 1998). Desse modo, inserido 


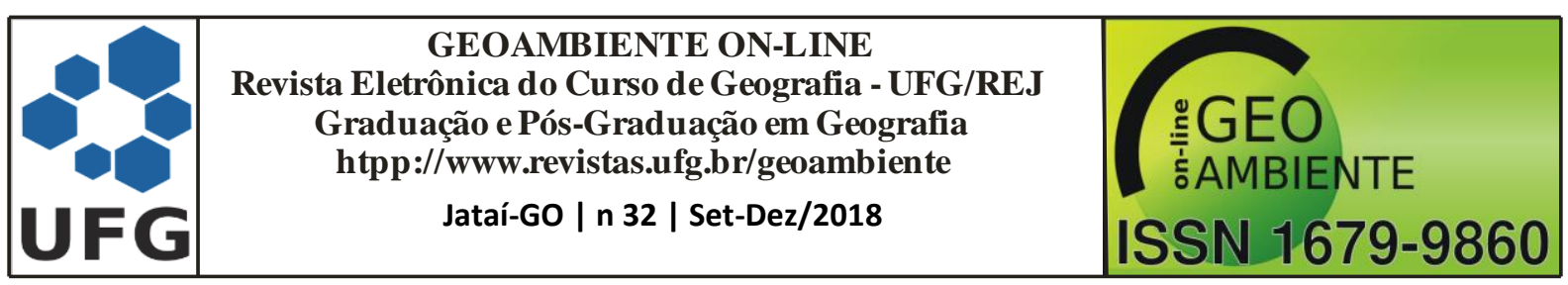

no rol dos estudos da dinâmica das paisagens, o zoneamento geoambiental se apresenta como um instrumento de planejamento ambiental territorial calcado no método integrador das informações ambientais (ROSS, 2006).

O zoneamento geoambiental consiste no resultado da análise interpretativa e integrativa dos elementos que compõem uma paisagem através de uma abordagem geossistêmica. Assim, o zoneamento supramencionado se constitui em um diagnóstico do meio físico-natural, a partir do estudo integrado da geologia, geomorfologia, cobertura vegetal, solo, clima e uso do solo, orientado para subsidiar o planejamento ambiental territorial.

Nessa perspectiva, a elaboração da proposta de zoneamento geoambiental para o município de Currais Novos está embasada na proposição de elaboração de instrumentos de planejamento ambiental do território. Nesse sentido, o objetivo principal deste trabalho é propor um zoneamento geoambiental para o município de Currais Novos - RN.

O município de Currais Novos (Figura 1) está localizado no Estado do Rio Grande do Norte. A área de estudo supramencionada apresenta diversidade paisagística associada a potencialidades de uso vegetal como matriz energética, que levou a um arranjo ambiental de degradação de solos e exaustão da vegetação nativa. Dessa forma, o zoneamento geoambiental do município de Currais Novos tem o propósito de compreender o meio em questão, ressaltando suas potencialidades e fragilidades frente às intervenções antrópicas.

Figura 1: Localização do município de Currais Novos

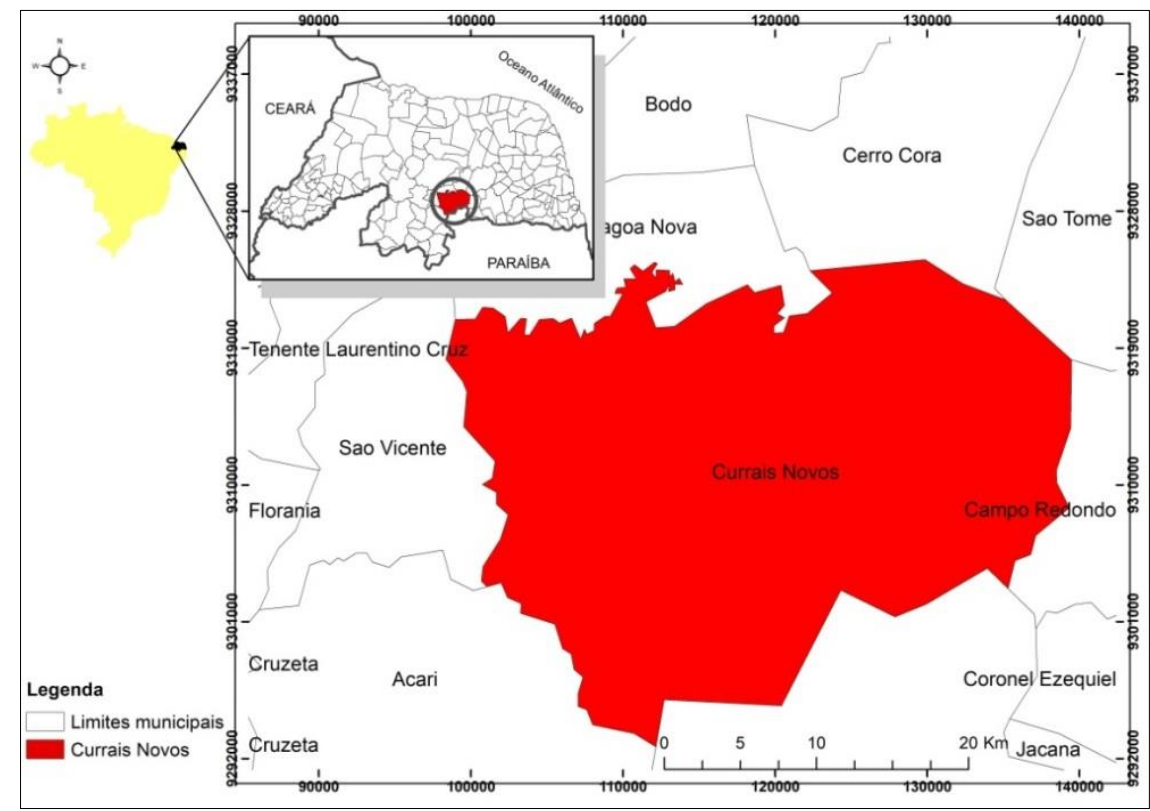




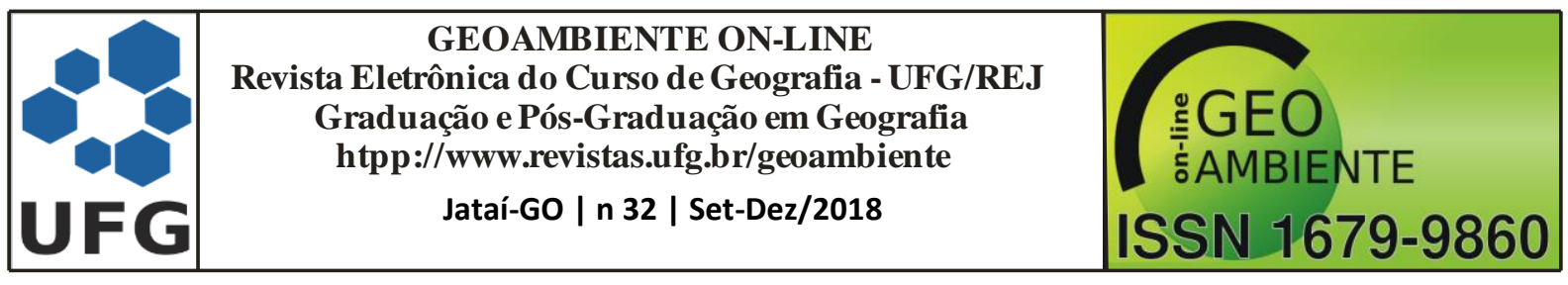

\section{Fundamentação teórica}

O zoneamento geoambiental consiste em compartimentar, com base nas características homogêneas, as unidades geoambientais que são obtidas a partir da integração dos dados de geomorfologia, geologia, solos, clima, vegetação e usos antropogênicos de um dado território. O estudo da geomorfologia é de extrema importância para uma análise sistêmica, no entanto, não se pode definir sistemas ambientais apoiado apenas nessa variável. É importante ressaltar que as formas do relevo não se constituem em variável definidora de Unidade da Paisagem. Nesse sentido Ross (2003, p. 12) esclarece que o "entendimento do relevo passa pela compreensão de uma coisa maior que é a paisagem como um todo". Não se pode entender a gênese e a dinâmica das formas do relevo sem antes entender os mecanismos motores de sua geração e as diferentes interferências dos demais componentes em uma determinada Unidade da Paisagem, pois existe relação estreita entre tipos de formas do relevo com os solos e estes com a litologia e o tipo climático atuante (ROSS, 2003).

Nesse sentido, a síntese desses elementos pode definir uma unidade de paisagem, esta, por sua vez, serve de base para delimitação de um zoneamento. Este zoneamento, segundo Santos (2004), se justifica como um instrumento do planejamento ambiental na medida em que compõe-se das fases de inventário e diagnóstico, que resultam na definição de áreas que compartimentam os diversos sistemas ambientais componentes do espaço estudado.

Com efeito, a síntese das unidades geoambientais obtidas a partir da análise dos elementos vivos e não vivos das paisagens, através de uma abordagem geossistêmica proposta por Sotchava (1960), é o que caracteriza o zoneamento geoambiental. Essa abordagem geossistêmica surgiu como uma adoção do conceito de sistema aos estudos da paisagem e trouxe inúmeras contribuições às análises de sistemas ambientais (PASSOS, 1988). Nesse contexto, Bertrand (1972) retoma a paisagem como um conceito cientifico, afirmando que ela é “em uma determinada porção do espaço, o resultado da combinação dinâmica, portanto instável, de elementos físicos, biológicos e antrópicos reagindo dialeticamente uns sobre os outros". Portanto, o geossistema é uma unidade complexa, por ser de difícil interpretação e que se caracteriza por certa homogeneidade de seus componentes, estruturas, fluxos e relações que, integrados, formam o ambiente físico onde há exploração biológica (TROPPMAIR, 2006). 


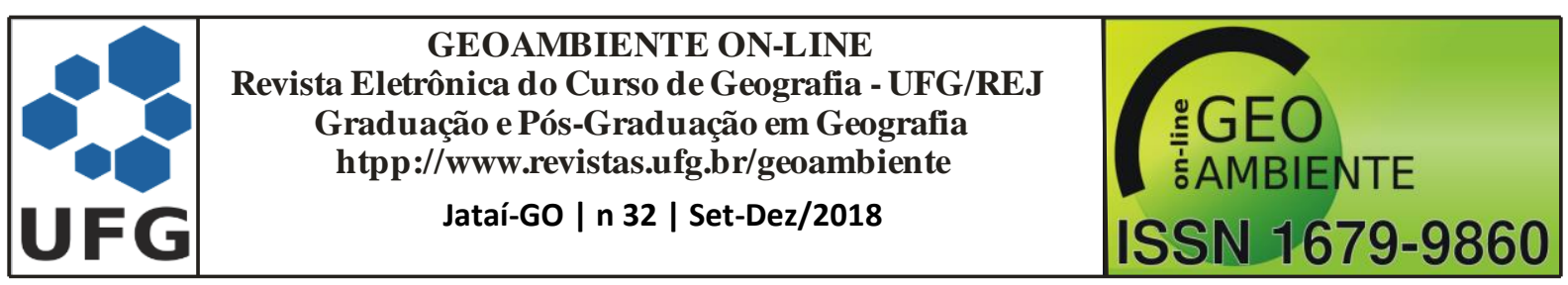

De acordo com Tricart (1977), os sistemas são como um conjunto de fenômenos que se processam mediante fluxos de matéria e energia e que originam relações de dependência mútua entre os fenômenos. A respeito dessa dinâmica o autor afirma que as trocas de energia e matéria na natureza se processam em relações de equilíbrio dinâmico. Para ele, as áreas em que prevalecem os processos morfogenéticos são entendidas como instáveis, enquanto que aquelas nas quais predomina a pedogênese são consideradas estáveis. Nesse sentido, o referido autor apresentou categorias para o estudo da paisagem denominadas de Unidades Ecodinâmicas, dividindo em três, a saber: meios estáveis, meios intergrades e meios fortemente instáveis.

Assim, a análise integrada da paisagem se constitui parte fundamental dos estudos geoambientais oferecendo entendimento das inter-relações e interdependências das partes diferenciadas entre si pelas funções que cada uma desempenha no conjunto global da paisagem, enfatizando suas formas, dinâmica e interferência antrópicas através do conhecimento de potencialidades e limitações, estabelecendo diretrizes preventivas e corretivas para os ambientes, auxiliando ao planejamento ambiental e ordenamento territorial.

Com efeito, a proposta de zoneamento geoambiental do município de Currais Novos se faz nessa perspectiva de conhecer o meio para utilizá-lo segundo a capacidade de suporte do ambiente.

\section{Procedimentos metodológicos}

Para alcançar o objetivo proposto nesta pesquisa foi necessária revisão bibliográfica, compilação de dados, mapas e produtos de sensoriamento remoto, trabalho de campo, produção de mapas temáticos em meio digital (formato shapefile) e integração de dados cartográficos através do método do overlay. Foram utilizados os seguintes materiais:

- Dados vetoriais do município estudado e rede de drenagem disponibilizados pelo IBGE (Instituto Brasileiro de Geografia e Estatística) em formato shapefile. Disponível em <http://www.ibge.gov.br/home/download/geociencias.shtm>.

- Mapa geológico do Estado do Rio Grande do Norte produzido pela CPRM (Serviço Geológico do Brasil) em escala 1:500.000 (ANGELIM et al., 2006);

- Mapa do "Levantamento exploratório - reconhecimento de solos do Estado do Rio Grande do Norte" elaborado pela SUDENE também em escala 1: 500.000 (SUDENE, 1971); 


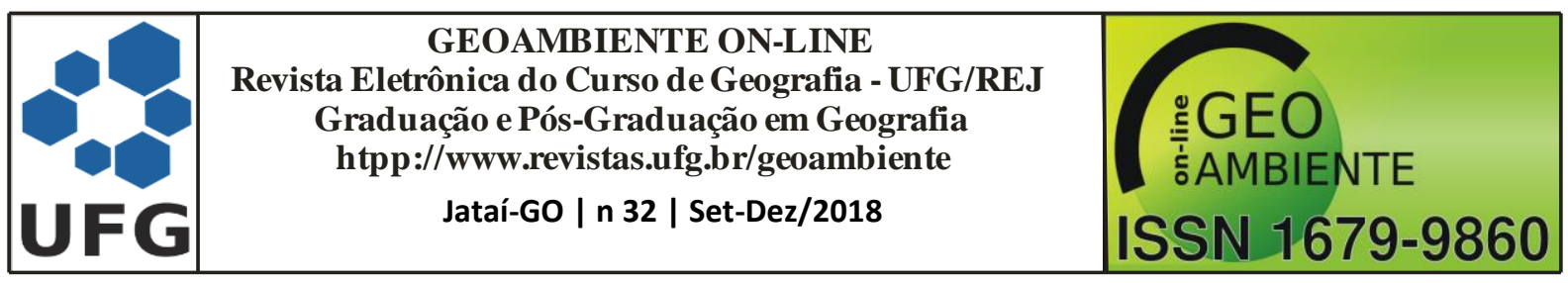

- Mapa exploratório de solos do Projeto RADAMBRASIL em escala 1:1.000.000 (BRASIL, 1981);

- Mapa de geomorfologia do Projeto RADAMBRASIL (BRASIL, 1981);

- Quadro das Unidades Geoambientais do Estado do Rio Grande do Norte (CESTARO, et al., 2007);

- Cartas topográficas da SUDENE (Superintendência do Desenvolvimento do Nordeste) na escala de 1: 100.000 - folhas Currais Novos (SB.24-Z-B-II) (SUDENE, 1972) e Cerro Corá (SB.24-Z-B-III) (SUDENE, 1985);

- $\quad$ Imagem Spot - cena 10 (Obtida em 2010)

- Imagem SRTM (Shuttlle Radar Topography Mission). Disponível em $<$ http://www2.jpl.nasa.gov/srtm/>.

- GPS (Sistema de Posicionamento Global), trena métrica e câmera fotográfica.

Utilizando esse material foram produzidos os mapas temáticos do modelo digital do terreno (MDT), declividade e curvas de nível a partir do tratamento de imagem SRTM; rede de drenagem, unidades geológicas, unidades geomorfológicas e solos a partir de vetorização dos mapas elencados nos materiais utilizados e unidades geoambientais a partir da integração dos dados anteriores através do método do overlay. Todos os mapas foram trabalhados no programa ArcGis em escala 1.100 .000 e ogeorreferenciamento foi validado com base na imagem spot.

O trabalho de campo foi realizado em duas etapas, a primeira de reconhecimento da área de estudo e a segunda para auxiliar nos trabalhos de mapeamento.

Depois de identificar, classificar, descrever e mapear as unidades geoambientais foi elaborado um quadro com as características geoambientais de Currais Novos utilizando a taxonomia proposta por Bertrand (1968) apoiado em Cestaro et al. (2007), cujo trabalho apresentou as categorias taxonômicas hierarquizadas em ordem decrescente em região natural, geossistema e geofácie adotada na elaboração do zoneamento geoambiental do Estado Rio Grande do Norte.

No entanto, devido a escala de trabalho, esse zoneamento apresenta limitações concernente a delimitação espacial e detalhamento das características dos sistemas geoambientais. Assim sendo, foram detalhados os limites espaciais dos sistemas e subsistemas geoambientais de Currais Novos, cujas nomenclaturas correspondem 


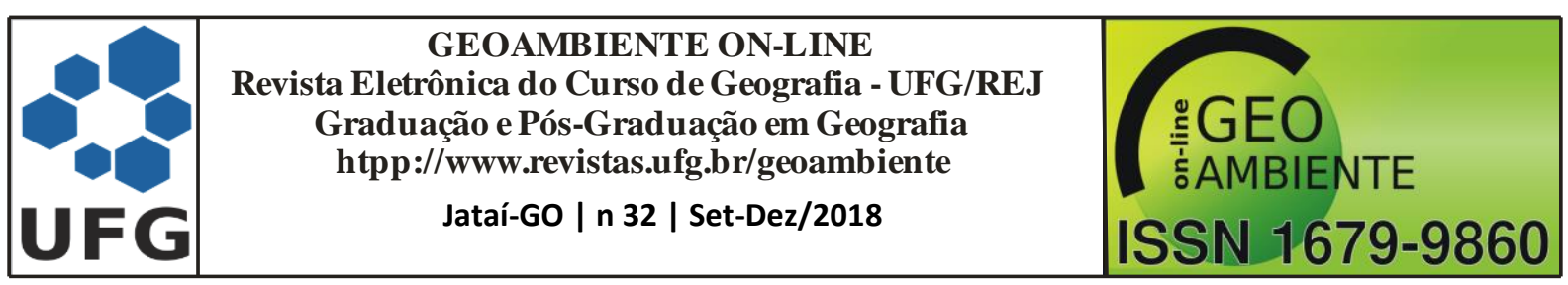

respectivamente as categorias taxonômicas de geossistema e geofácie adotada no trabalho comparativo supramencionado.

Por fim, reconhecidas as unidades geoambientais e as características físico-ambientais de cada uma delas, foram estudadas e apresentadas as aptidões e restrições das unidades geoambientais, revelando as potencialidades e fragilidades quanto ao uso do solo do município de Currais Novos.

\section{Resultados e discussões}

Após a aplicação da metodologia supracitada e considerando uma análise sistêmica do ambiente estudado, definiram-se as seguintes unidades geoambientais (Quadro 1) que serviram de base para o zoneamento ora proposto.

Quadro 1: Classificação dos sistemas geoambientais do município de Currais Novos.

\begin{tabular}{|l|l|}
\hline \multicolumn{2}{|c|}{ Classificação proposta } \\
\hline \multirow{2}{*}{ Unidades Geoambientais } \\
\hline \multirow{2}{*}{ Planalto da Borborema } & Subsistema Geoambiental \\
\hline \multirow{2}{*}{ Planalto Residual } & Planalto da Borborema Encosta Oriental \\
\cline { 2 - 2 } & Planalto da Borborema Encosta Ocidental \\
\cline { 2 - 2 } & Maciços Isolados do Planalto da Borborema \\
\hline \multirow{2}{*}{ Chapada da Serra de Santana } & Cristas Residuais \\
\cline { 2 - 2 } & Maciços Residuais \\
\hline Vale Fluvial Semiárido & Chapada de Topo Plano \\
\cline { 2 - 2 } & Escarpa Erosiva da Chapada \\
\hline Vale Lagunar & Planície de Inundação Fluvial \\
\cline { 2 - 2 } & Rio Temporário do Semiárido \\
\hline
\end{tabular}

Organização: Autores

Assim, considerando as propostas e metodologias de um zoneamento, torna-se importante representar cartograficamente os sistemas e subsistemas encontrados na pesquisa.

Desse modo, segue a representação cartográfica do Zoneamento Geoambiental do município de Currais Novos (Figura 2), acompanhada das caracterizações físico/ambientais de cada unidade: 


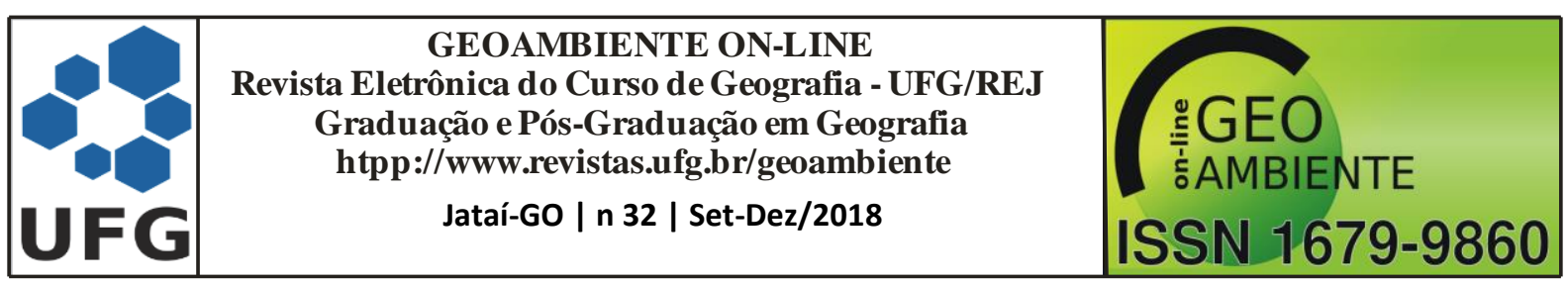

Figura 2: Proposta de Zoneamento Geoambiental do município de Currais Novos

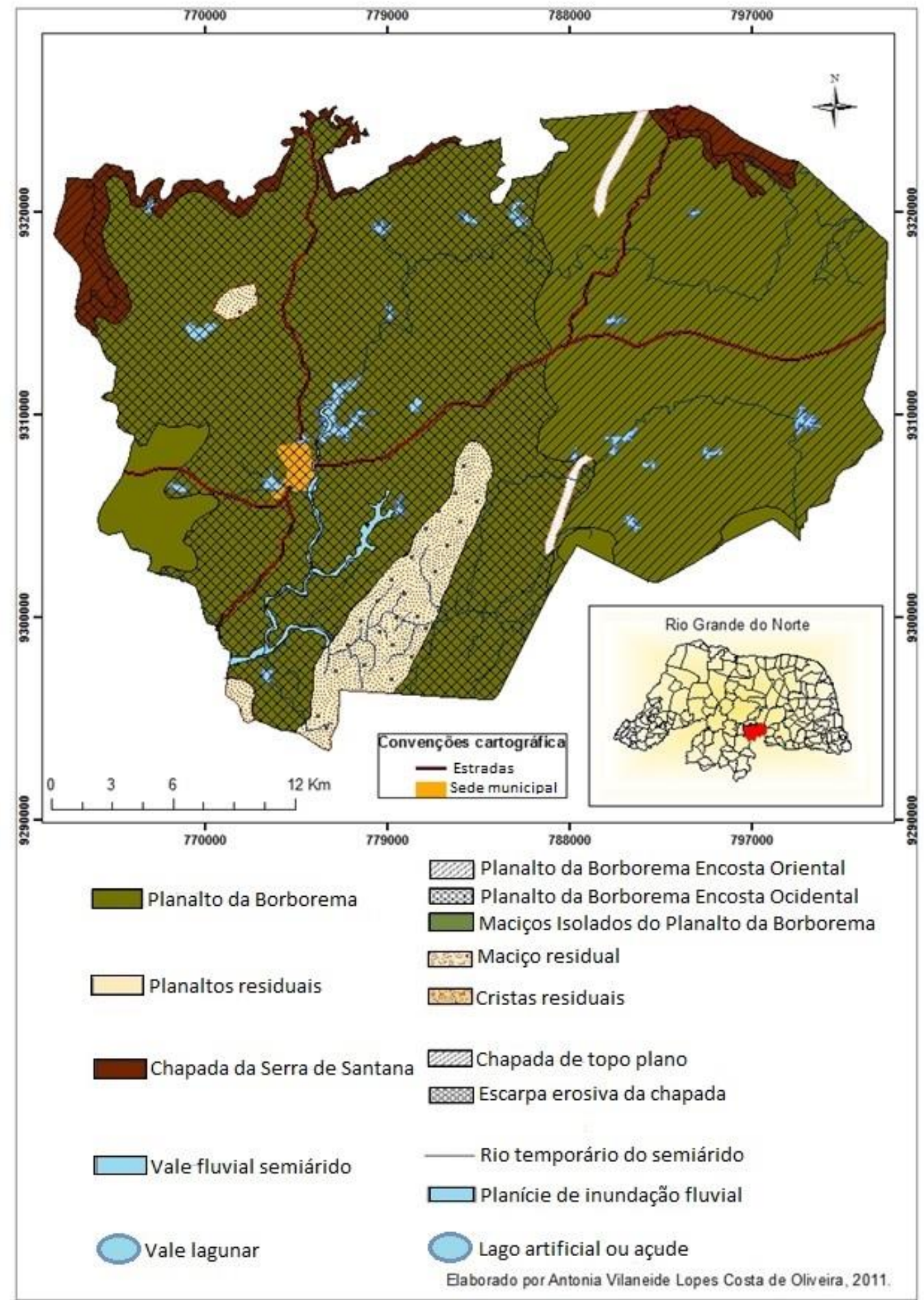

Organização: autores

Caracterização dos Sistemas Geoambientais do município de Currais Novos 


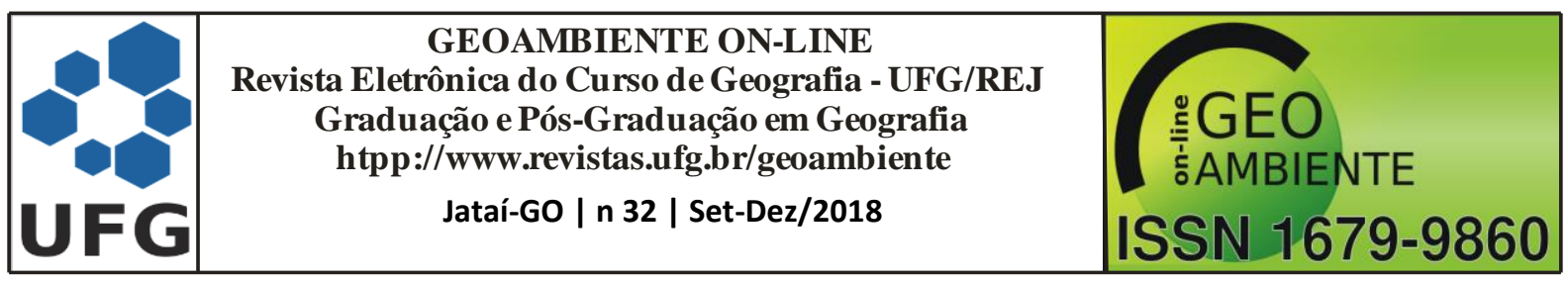

A compartimentação geoambiental do município de Currais Novos resultou em cinco sistemas e onze subsistemas. Assim, quanto aos Sistemas Geoambientais, têm-se as seguintes caracterizações:

\section{Sistema Geoambiental Planalto da Borborema}

O Sistema Geoambiental Planalto da Borborema (Figura 3) compreende os subsistemas geoambientais Planalto da Borborema Encosta Oriental, Planalto da Borborema Encosta Ocidental e Maciços isolados do Planalto da Borborema.

- Planalto da Borborema Encosta Oriental

Geologia/Geomorfologia: Formado predominantemente pela Formação Seridó com enclaves da Formação Equador e Formação Jucurutu, bem como da Suíte Intrusiva Dona Inez. Apresenta relevo ondulado e com superfícies inclinadas com altimetria variando de $400 \mathrm{~m}$ a $600 \mathrm{~m}$ e intensidade de dissecação do relevo muito fraca.

Condições hidroclimáticas: Condições de clima semiárido com precipitação anual irregular com oscilações de $400 \mathrm{~mm}$ a $600 \mathrm{~mm}$ anuais. Drenagem de caráter intermitente com predominância de riachos com baixo potencial hidrológico.

Solos e cobertura vegetal: Predomina associação de Neossolos com Luvissolos e área recoberta por Caatinga Hiperxerófila do Seridó com áreas de forte degradação onde é possível verificar processos de desertificação.

- Planalto da Borborema Encosta Ocidental

Geologia/Geomorfologia: Predomina a Formação Seridó, no entanto ocorre uma maior diversidade de enclaves de formações geológicas como Formação Equador e Formação Jucurutu, bem como suíte intrusivas como a Suíte Dona Inez, Suíte Itaporanga, Suíte São João do Sabugi e Suíte Poço da Cruz. Apresenta relevo ondulado e com superfícies inclinadas a fortemente inclinada com altimetria variando em torno de $320 \mathrm{~m}$ a $450 \mathrm{~m}$ e intensidade de dissecação fraca a muito fraca.

Condições hidroclimáticas: Condições de clima semiárido com precipitação anual irregular com oscilações de $400 \mathrm{~mm}$ a $600 \mathrm{~mm}$ anuais. Área onde são observados os principais rios do município com drenagem de caráter intermitente e padrão de drenagem tipo dendrítico. 


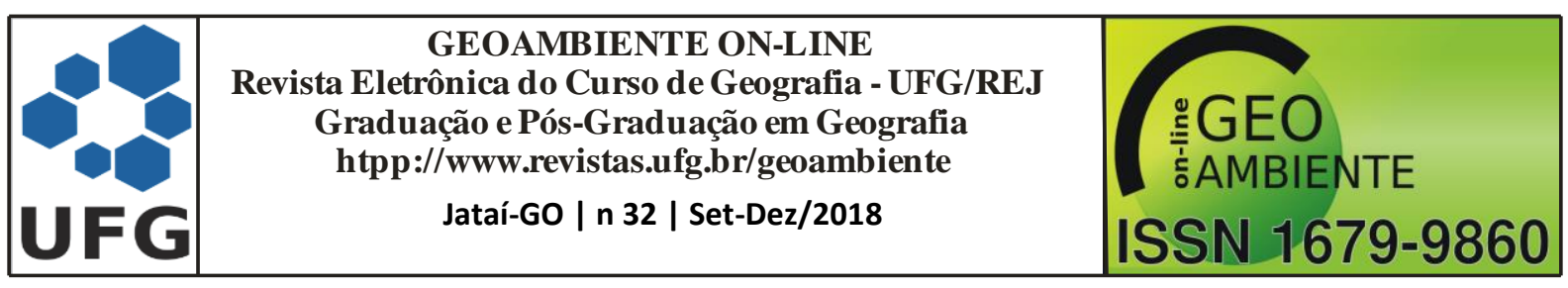

Solos e cobertura vegetal: Apresenta associação de Neossolos e Luvissolos recoberto por Caatinga Hiperxerófila do Seridó, Floresta Subcaducifólia e Mata Ciliar muitas vezes sendo substituída por plantações de capim.

- Maciços isolados do Planalto da Borborema

Geologia/Geomorfologia: Apresentam-se em áreas não continuas como restos de superfícies sendo observados mais claramente em duas áreas do município. A primeira na porção sudeste do município, divisa com o Estado da Paraíba. Observa-se um relevo de superfície conservada com topo plano e limitado por escarpas, capeados por rochas sedimentares da Formação Serra do Martins com altimetria aproximada de 650 m. Já segunda área é observada na porção sudoeste do município, em área de relevo com superfície fortemente inclinada, representado pela Formação Jucurutu com altimetria aproximada de 500 m.

Condições hidroclimáticas: No contexto regional esse subsistema esta inserido em clima semiárido, no entanto, as temperaturas são amenas nessas áreas. São pouco drenados devido às condições geomorfológicas.

Solos e cobertura vegetal: Os solos apresentam uma associação de Neossolos, Luvissolos e Planossolos. Com cobertura vegetal de caatinga mais densa e de porte mais elevado.

Figura 3: Planalto da Borborema

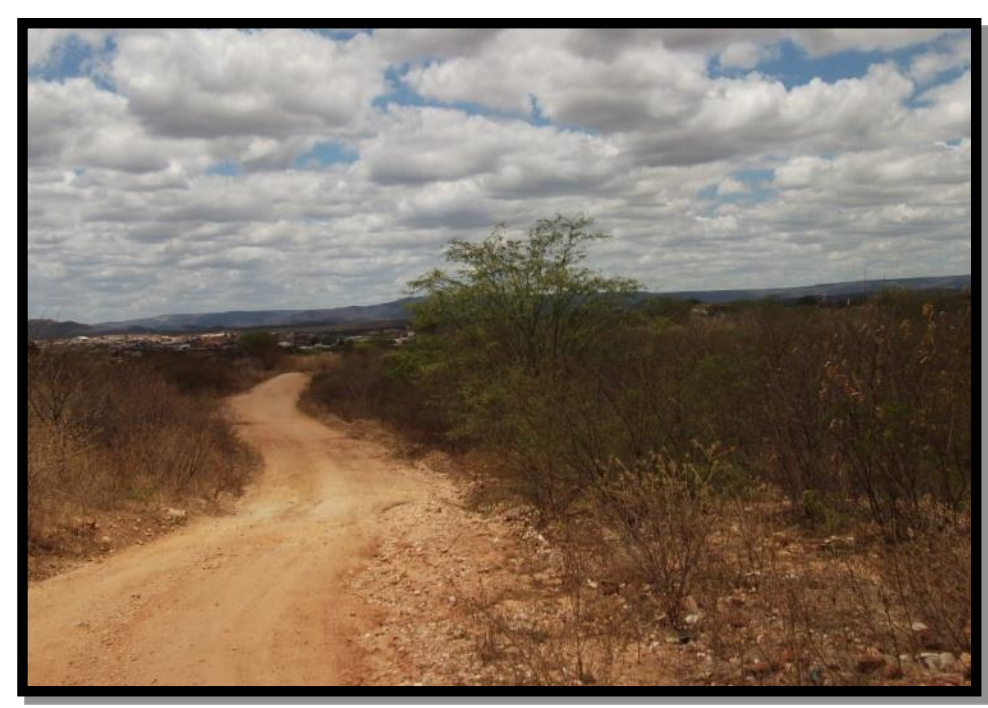

Fonte: Autora, 2011. 


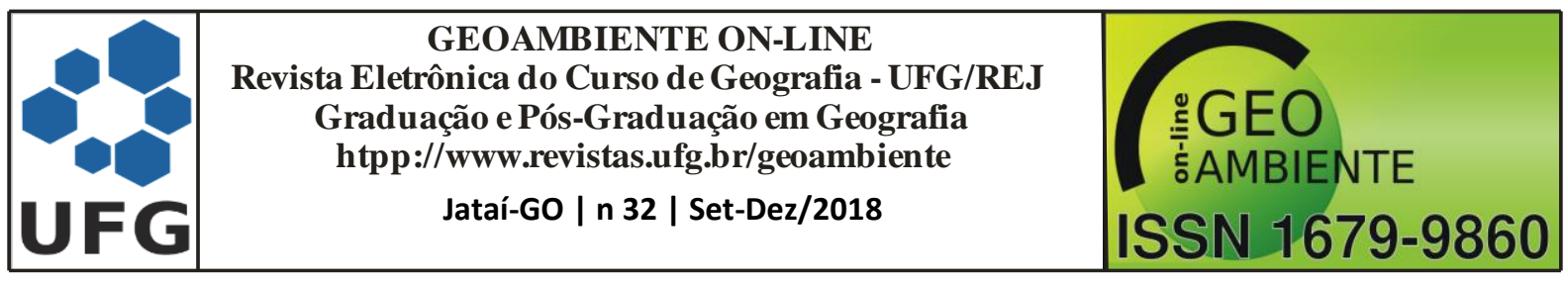

\section{Sistema Geoambiental Planalto Residual}

No Sistema Geoambiental Planalto Residual (Figura 4) encontram-se os subsistemas de Maciços Residuais e Cristas residuais.

\section{- Maciços Residuais}

Geologia/Geomorfologia: Observadas na porção norte e sudeste do município. O maciço da porção sudeste é denominado de Serra do Acauã. Constitui-se em forma típica na região, pois é um afloramento em constante processo de erosão, se constituindo em superfície de erosão, ondulada do tipo "pão-de-açúcar" formado pela Suíte Intrusiva Dona Inez. É importante destacar outros maciços relevantes na paisagem de Currais Novos, como os maciços graníticos de topos tabulares que possuem trechos dissecados em cristas separadas por vales em "V". Nessa formação, o vale formado apresenta um cenário geomorfológico em forma de canyon, chamado de Apertados, por onde passa o Rio Acauã.

Condições hidroclimáticas: Inserido em clima semiárido com precipitação anual irregular oscilando de $400 \mathrm{~mm}$ a $600 \mathrm{~mm}$ anuais. Apresenta drenagem composta por rios e riachos intermitentes que atravessam vales ou permeia as áreas mais baixas dessas formações.

Solos e cobertura vegetal: Essas estruturas se apresentam, na maioria das vezes, como afloramento rochoso, com uma fina camada de Neossolos. No entanto, o município possui uma estrutura residual alongada no sentido nordeste - sudoeste que apresenta área de deposição compostas por solos profundos, recobertos por pequenos aglomerados de vegetação de caatinga de porte baixo e cactáceas.

- Cristas residuais

Geologia/Geomorfologia: Outra forma de maciço residual encravado nesse sistema ambiental e encontrado com frequência no município de Currais Novos são as formas de dissecação denominadas de cristas. Estas apresentam-se na direção nordeste - sudeste, paralela ao Rio Currais Novos e são representantes da Formação Jucurutu.

Condições hidroclimáticas: Inserido em clima semiárido com precipitação anual irregular oscilando de $400 \mathrm{~mm}$ a $600 \mathrm{~mm}$ anuais. Apresenta uma drenagem que se restringe a riachos intermitentes que passam nos espaços das formações rochosas.

Solos e cobertura vegetal: Apresenta Neossolos recoberto por pequenos aglomerados de vegetação de caatinga de porte baixo e cactáceas. 


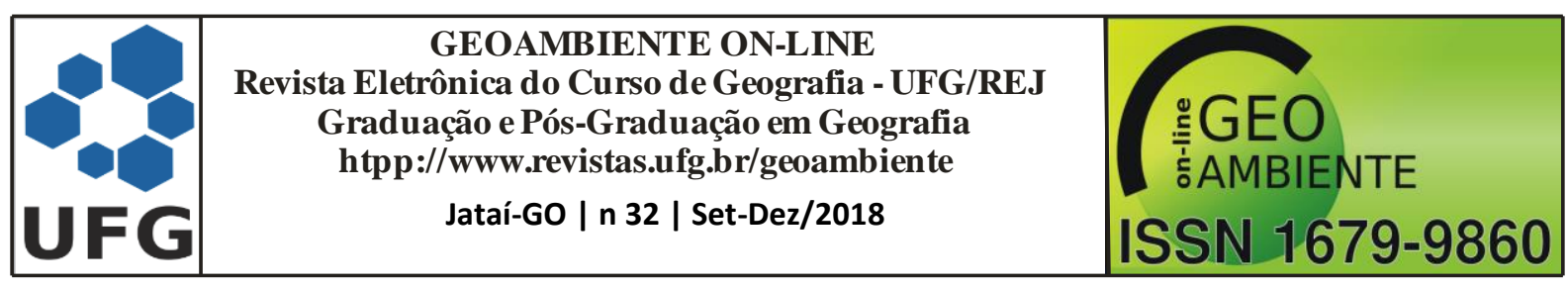

Figura 4: Planalto Residual

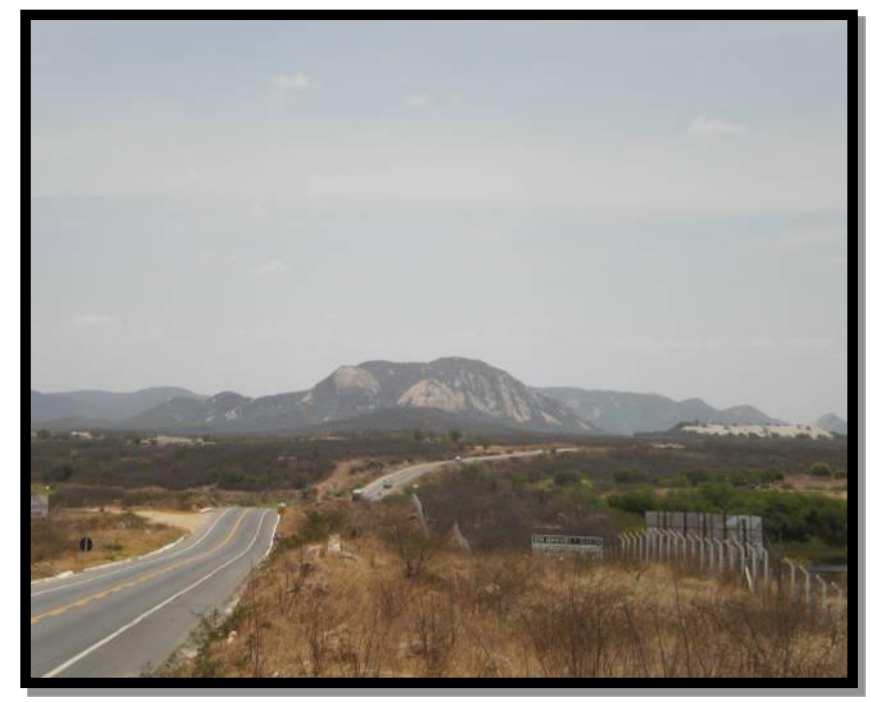

Fonte: Autora, 2011.

\section{Sistema Geoambiental Chapada da Serra de Santana}

No Sistema Geoambiental Chapada da Serra de Santana (Figura 5) estão compreendidos os subsistemas Chapada de topo plano e Escarpa erosiva da chapada.

- Chapada de topo plano

Geologia/Geomorfologia: É constituída por material arenítico sedimentar pertencente a Formação Serra do Martins, depositado no Cretáceo Superior. Essa área é caracterizada por superfície de topo plano e tabular, se constituindo em superfície tabular erosiva, podendo atingir uma altitude de $800 \mathrm{~m}$.

Condições hidroclimáticas: No contexto regional essa área está inserida em clima semiárido, no entanto, as condições de temperatura e precipitação são diferenciadas das demais áreas do município de Currais Novos. As temperaturas, nesse subsistema, podem chegar a $12^{\circ}$ C. Na Serra de Santana as drenagens fluem de forma radial-centrifuga, caracterizando este platô como um divisor de água (MENEZES, 1999).

Solos e cobertura vegetal: Apresenta Latossolos, solos de Aluvião e cobertura vegetal de Floresta Subcaducifólia.

- $\quad$ Escarpa erosiva da chapada. 


\begin{tabular}{|c|c|c|}
\hline & $\begin{array}{c}\text { GEOAMBIENTE ON-LINE } \\
\text { Revista Eletrônica do Curso de Geografia - UFG/REJ } \\
\text { Graduação e Pós-Graduação em Geografia } \\
\text { htpp://www.revistas.ufg.br/geoambiente } \\
\text { Jataí-Go | n } 32 \text { | Set-Dez/2018 }\end{array}$ & $\begin{array}{c}\text { :GEO } \\
\text { J }\end{array}$ \\
\hline
\end{tabular}

Geologia/Geomorfologia: Área de relevo fortemente inclinado com altitudes que chegam a $600 \mathrm{~m}$.

Condições hidroclimáticas: Corresponde a uma área relativamente úmida, comparada ao seu entorno sul. Com presença de riachos intermitentes advindos do topo da chapada.

Solos e cobertura vegetal: Apresenta Neossolos e vegetação característica de área de transição com representantes de Caatinga arbustiva e de Floresta Subcaducifólia.

Figura 5: Chapada da Serra de Santana

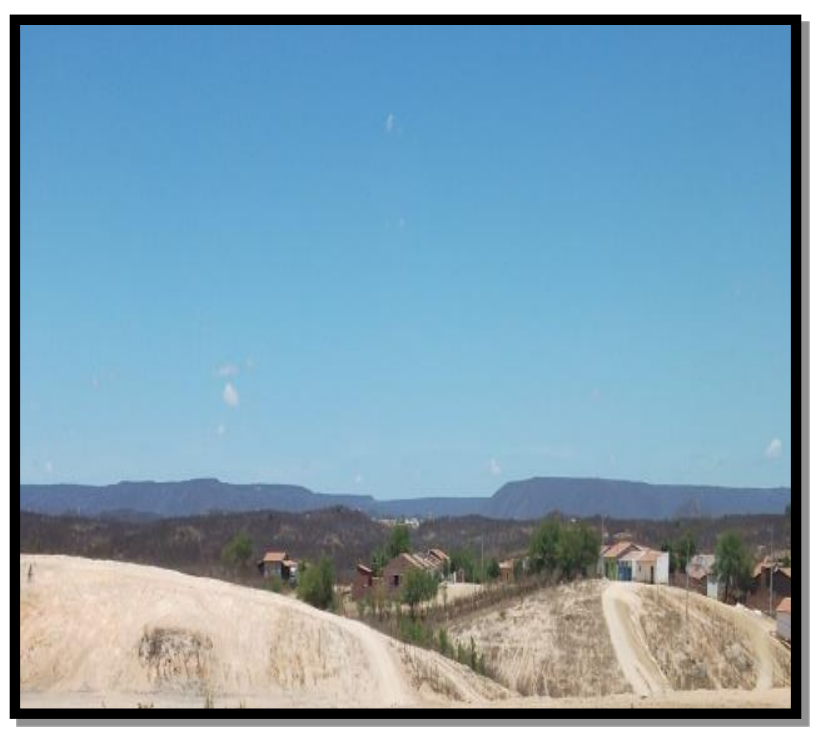

Fonte: Autora, 2011.

\section{Sistema Geoambiental Vale Fluvial Semiárido}

O Sistema Geoambiental Vale Fluvial Semiárido (Figura 6) compreende os subsistemas Planície de inundação fluvial e Rio temporário do semiárido.

- Planície de inundação fluvial

Geologia/Geomorfologia: Constituído por depósitos aluvionares em áreas mais rebaixadas cuja altimetria fica em torno de $310 \mathrm{~m}$.

Condições hidroclimáticas: Formado por rios intermitentes e condicionadas a um clima semiárido, cujas precipitações médias anuais oscilam em torno de $400 \mathrm{~mm}$ a $600 \mathrm{~mm}$. 


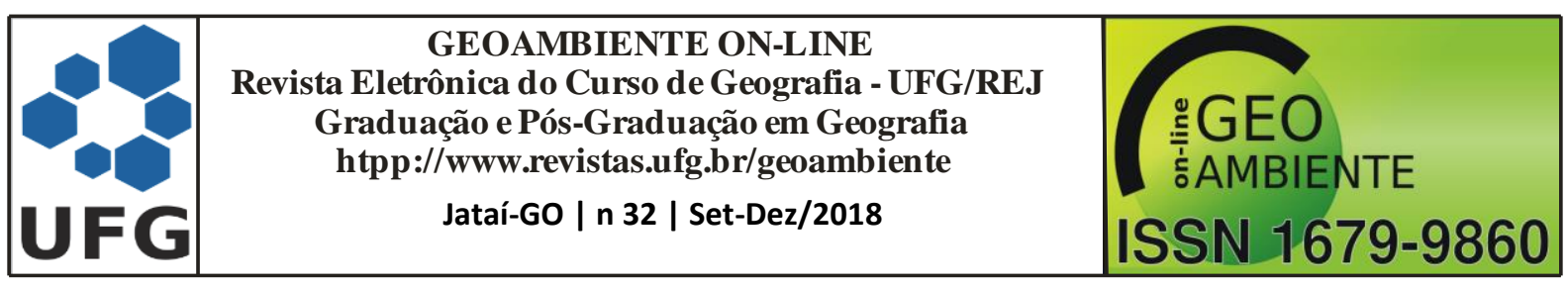

Solos e cobertura vegetal: Predomina os Neossolos flúvicos e encontra-se recoberto por vegetação de Mata Ciliar fortemente degradada, predominando vegetação secundária e plantações de capim.

- Rio temporário

Geologia/Geomorfologia: Os rios temporários apresentados são aqueles que não se constituem em Planície de inundação fluvial. Assim, esses rios se apresentam predominantemente em área da formação Seridó, em relevo ondulado e com superfícies inclinadas a fortemente inclinada com altimetria que varia em torno de $450 \mathrm{~m}$ a $500 \mathrm{~m}$.

Condições hidroclimáticas: Condições de clima semiárido com precipitação anual irregular, oscilações de $400 \mathrm{~mm}$ a $600 \mathrm{~mm}$ anuais. Drenagem de caráter intermitente com predominância de riachos com baixo potencial hidrológico.

Solos e cobertura vegetal: Predomina associação de solos Neossolos mais Luvissolos. A vegetação é representada pela Caatinga Hiperxerófila do Seridó, com áreas fortemente degradadas.

Figura 6: Vale Fluvial Semiárido

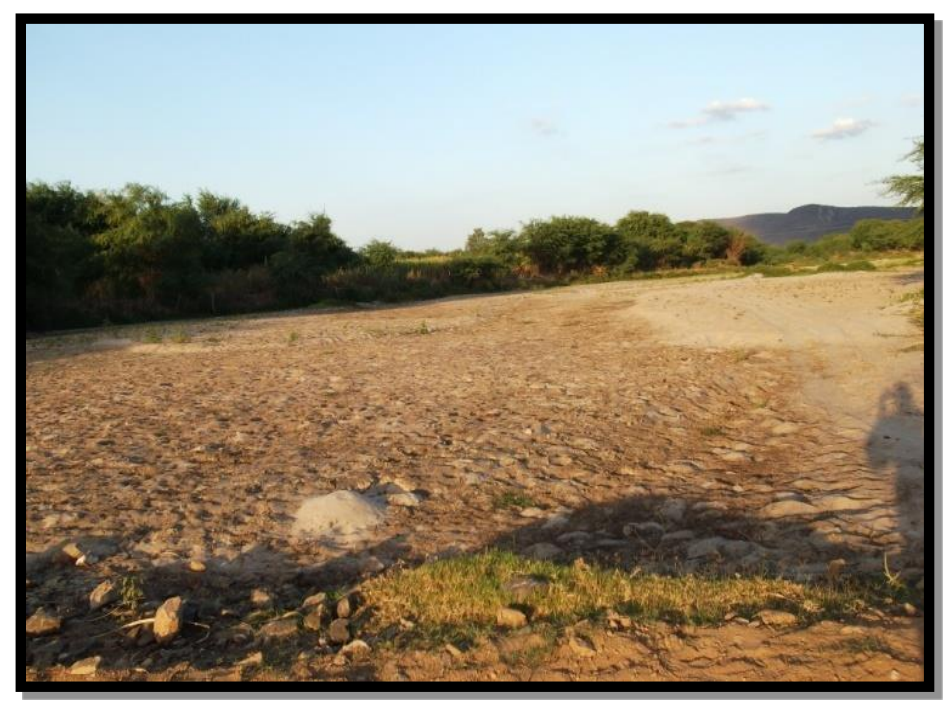

Fonte: Autora, 2011.

\section{Sistema Geoambiental Vale Lagunar}

De acordo com as características propostas para o Sistema Geoambiental Vale Lagunar, (Figura 7) o município de Currais Novos apresenta um subsistema: subsistema geoambiental 


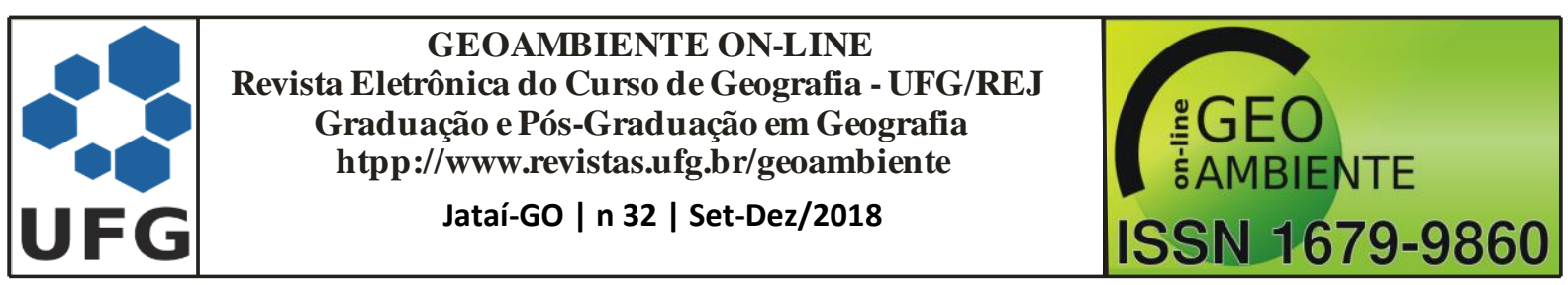

Lago artificial ou açude. São considerados como parte desse subsistema apenas os açudes que apresentaram um perímetro de espelho d'água superior a $2 \mathrm{~km}$ em período chuvoso.

- Lago artificial ou açude

Geologia/Geomorfologia: Esses lagos artificiais foram construídos em áreas diversas predominantemente da Formação seridó.

Condições hidroclimáticas: Condições de clima semiárido com precipitação anual irregular, oscilações de $400 \mathrm{~mm}$ a $600 \mathrm{~mm}$ anuais. São corpos d'água que, por vezes, captam água de rios e riachos intermitentes.

Solos e cobertura vegetal: Predomina associação de Neossolos mais Luvissolos. A vegetação é representada pela Caatinga Hiperxerófila do Seridó e Mata Ciliar que se constituíram ao longo do tempo.

Figura 7: Vale Lagunar

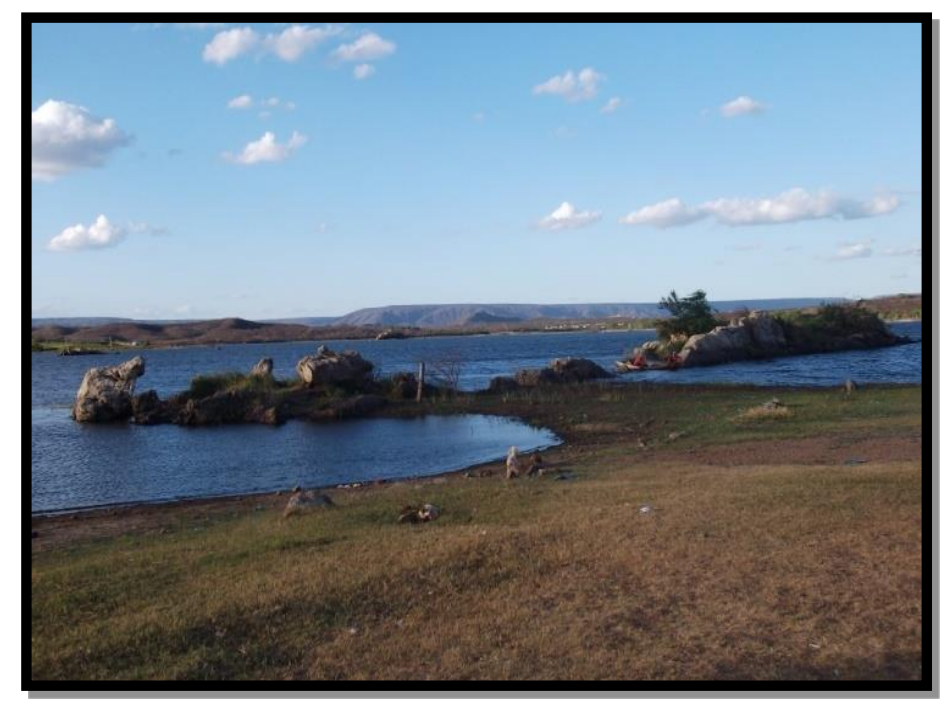

Fonte: Autora, 2011.

\section{Potencialidades e limitações dos Sistemas Geoambientais do município de Currais Novos}

A partir do conhecimento integrado dos aspectos físicos de uma área é possível conhecer suas potencialidades e fragilidades de uso. Nesse sentido, conhecer os aspectos ambientais do município de Currais Novos foi importante, pois o processo de descrição serviu para compor um quadro síntese (quadro 2) sobre o meio, que levou a compreensão dos 


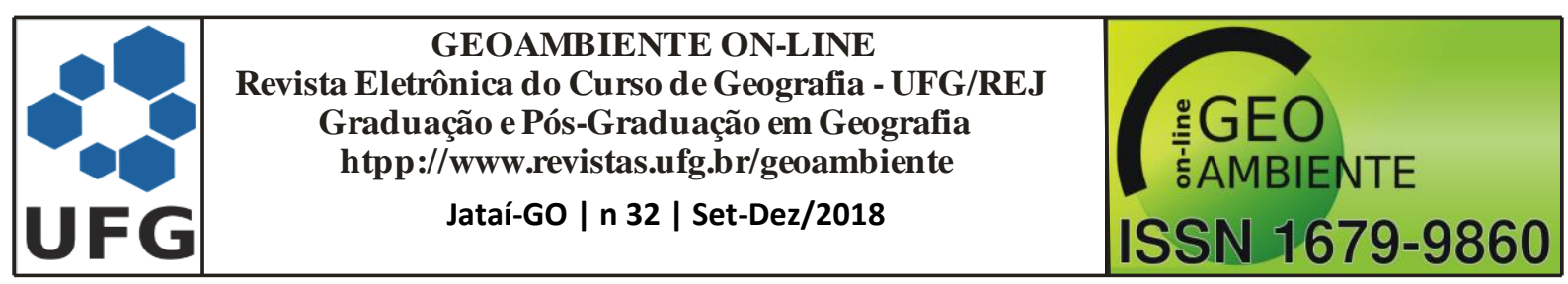

atributos potenciais e das fragilidades. Esse trabalho resultou em propostas de uso do solo, conservação de áreas e melhoria da qualidade de vida, vinculado à capacidade de suporte do ambiente.

Quadro2. Síntese informativa com a análise integrada dos elementos da paisagem

\begin{tabular}{|c|c|c|c|}
\hline $\begin{array}{c}\text { Subsistema } \\
\text { Geoambiental }\end{array}$ & Potencialidades & $\begin{array}{c}\text { Limitações naturais para o uso } \\
\text { econômico }\end{array}$ & Usos atuais \\
\hline $\begin{array}{l}\text { Planície de } \\
\text { Inundação } \\
\text { Fluvial }\end{array}$ & $\begin{array}{l}\text { Solos com alta fertilidade e } \\
\text { profundos, favorável a vários } \\
\text { cultivos. Além disso, são solos } \\
\text { de boa utilização na } \\
\text { construção civil e ceramista. }\end{array}$ & $\begin{array}{l}\text { A própria característica de ambiente } \\
\text { reservado à conservação faz desta } \\
\text { unidade limitante para usos } \\
\text { exploratórios. }\end{array}$ & $\begin{array}{l}\text { Extração de } \\
\text { solo para } \\
\text { cerâmicas. } \\
\text { Cultivos } \\
\text { diversos r e } \\
\text { pecuária. }\end{array}$ \\
\hline $\begin{array}{l}\text { Chapada de } \\
\text { Topo Plano }\end{array}$ & $\begin{array}{l}\text { Solos favoráveis à fruticultura. } \\
\text { O relevo com topografia plana } \\
\text { a suavemente ondulada, } \\
\text { declividade baixa associada às } \\
\text { condições de temperaturas } \\
\text { amenas favoráveis a } \\
\text { agropecuária } \\
\text { desenvolvimento de atividades } \\
\text { voltadas para o turismo. }\end{array}$ & $\begin{array}{l}\text { Solos distróficos de } \text { baixa fertilidade } \\
\text { muitas vezes } \\
\text { desfavoráveis ao } \\
\text { desenvolvimento } \\
\text { agrícola. }\end{array}$ & 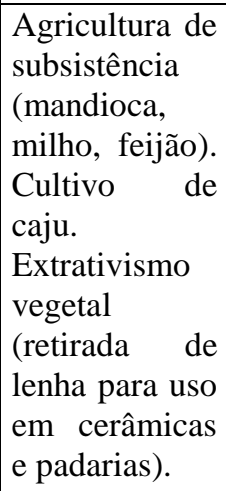 \\
\hline $\begin{array}{l}\text { Escarpa Erosiva } \\
\text { da Chapada }\end{array}$ & $\begin{array}{l}\text { Solos férteis com potencial } \\
\text { agrícola. }\end{array}$ & $\begin{array}{l}\text { Predomina relevo } \text { ondulado com } \\
\text { declives acentuados que aumentam os } \\
\text { processos erosivos restringindo as } \\
\text { atividades agrícolas. }\end{array}$ & $\begin{array}{l}\text { Pecuária, } \\
\text { agricultura, } \\
\text { extração de } \\
\text { lenha. }\end{array}$ \\
\hline $\begin{array}{l}\text { Planalto da } \\
\text { Borborema } \\
\text { Encosta } \\
\text { Ocidental }\end{array}$ & $\begin{array}{l}\text { Favoráveis à plantação de } \\
\text { milho, feijão e algodão } \\
\text { arbóreo. }\end{array}$ & 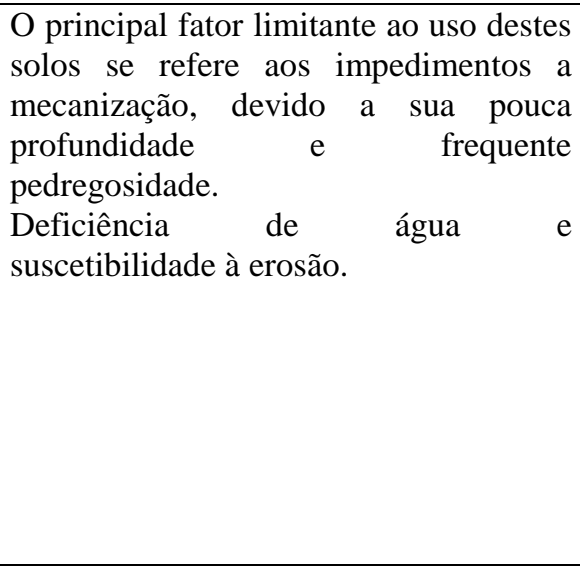 & $\begin{array}{ll}\text { Culturas de } & \text { de } \\
\text { ciclo curto e } & \\
\text { pecuária } & \\
\text { extensiva. } & \\
\text { Extração da } & \text { da } \\
\text { vegetação } & \\
\text { natural } & \text { e } \\
\text { cultivo de } & \text { subsistência. } \\
\text { Exploração } & \\
\text { mineral. } & \\
\text { Áreas } & \text { de } \\
\text { expansão } & \\
\text { urbana. } & \\
\end{array}$ \\
\hline
\end{tabular}




\begin{tabular}{|c|c|c|}
\hline & $\begin{array}{c}\text { GEOAMBIENTE ON-LINE } \\
\text { Revista Eletrônica do Curso de Geografia - UFG/REJ } \\
\text { Graduação e Pós-Graduação em Geografia } \\
\text { htpp://www.revistas.ufg.br/geoambiente } \\
\text { Jataí-Go | n } 32 \text { | Set-Dez/2018 }\end{array}$ & $\begin{array}{c}\text { :GEO } \\
\text { J }\end{array}$ \\
\hline
\end{tabular}

\begin{tabular}{|c|c|c|c|}
\hline $\begin{array}{l}\text { Planalto da } \\
\text { Borborema } \\
\text { Encosta } \\
\text { Oriental }\end{array}$ & $\begin{array}{l}\text { Favoráveis à plantação de } \\
\text { milho, feijão e algodão } \\
\text { arbóreo. Na maior parte da } \\
\text { área pode ser associado com a } \\
\text { pecuária extensiva. }\end{array}$ & $\begin{array}{l}\text { Condições físicas do solo desfavoráveis } \\
\text { a mecanização devido à ocorrência de } \\
\text { pedregosidade, rochosidade e pouca } \\
\text { profundidade. } \\
\begin{array}{l}\text { Deficiência de água } \\
\text { suscetibilidade à erosão. }\end{array}\end{array}$ & 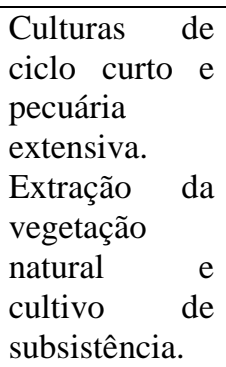 \\
\hline $\begin{array}{ll}\text { Maciços } & \\
\text { Isolados } & \text { do } \\
\text { Planalto } & \text { da } \\
\text { Borborema } & \end{array}$ & $\begin{array}{l}\text { Áreas no sopé dos maciços } \\
\text { apropriadas para agricultura. } \\
\text { Potencial para turismo } \\
\text { ecológico ou científico. }\end{array}$ & $\begin{array}{l}\text { Predomina relevo com declividade } \\
\text { acentuada o que intensifica os processos } \\
\text { erosivos. } \\
\text { Fortes restrições a expansão da } \\
\text { ocupação humana e das atividades } \\
\text { agropecuárias. Baixo potencial hídrico } \\
\text { superficial e subterrâneo. Solos } \\
\text { imperfeitamente drenados, de baixa } \\
\text { permeabilidade e muito susceptíveis à } \\
\text { erosão. São solos que apesar da } \\
\text { fertilidade natural alta, apresentam } \\
\text { fortes limitações pela falta d'águas. A } \\
\text { irrigação nestes solos é problemática, } \\
\text { visto que os mesmos são rasos, } \\
\text { apresentam problemas de manejo e } \\
\text { normalmente possuem considerável teor } \\
\text { de sódio trocável na parte baixa dos } \\
\text { perfis, cuja tendência é aumentar, caso a } \\
\text { irrigação não seja bem conduzida. }\end{array}$ & $\begin{array}{l}\text { Exploração de } \\
\text { lenha. } \\
\text { Agricultura e } \\
\text { pecuária. }\end{array}$ \\
\hline $\begin{array}{l}\text { Maciços } \\
\text { residuais }\end{array}$ & $\begin{array}{l}\text { Em algumas áreas apresenta } \\
\text { solos de boa fertilidade natural } \\
\text { favorável ao desenvolvimento } \\
\text { da atividade agrícola na } \\
\text { porção de menor declividade. } \\
\text { Exploração de material } \\
\text { arenoso utilizado na } \\
\text { construção civil. Além de } \\
\text { potencial turístico devido ao } \\
\text { cenário geomorfológico em } \\
\text { forma de vale (Apertados) ou } \\
\text { Picos (Pico do Totoró). } \\
\text { Apresenta também potencial } \\
\text { para área destinada à } \\
\text { conservação, como exemplo, a } \\
\text { criação de RPPN's. }\end{array}$ & $\begin{array}{l}\text { Predomina } \text { relevo com declividade } \\
\begin{array}{l}\text { acentuada o que } \\
\text { processos erosivos. }\end{array} \\
\begin{array}{l}\text { Restriçõonsifica } \\
\text { ocupação humana devido a declividade. }\end{array}\end{array}$ & $\begin{array}{l}\text { Extração de } \\
\text { material } \\
\text { arenoso e de } \\
\text { lenha. } \\
\text { Exploração } \\
\text { mineral. } \\
\text { Atividades } \\
\text { agropecuárias. }\end{array}$ \\
\hline
\end{tabular}

Fonte: Autor (2011), baseado no trabalho de campo.

\section{Considerações finais}

O município de Currais Novos possui uma diversidade paisagística, resultando em sistemas ambientais também diversos. A análise dos elementos do meio físico desse município permite afirmar que essa área de estudo possui potencial para as atividades de 


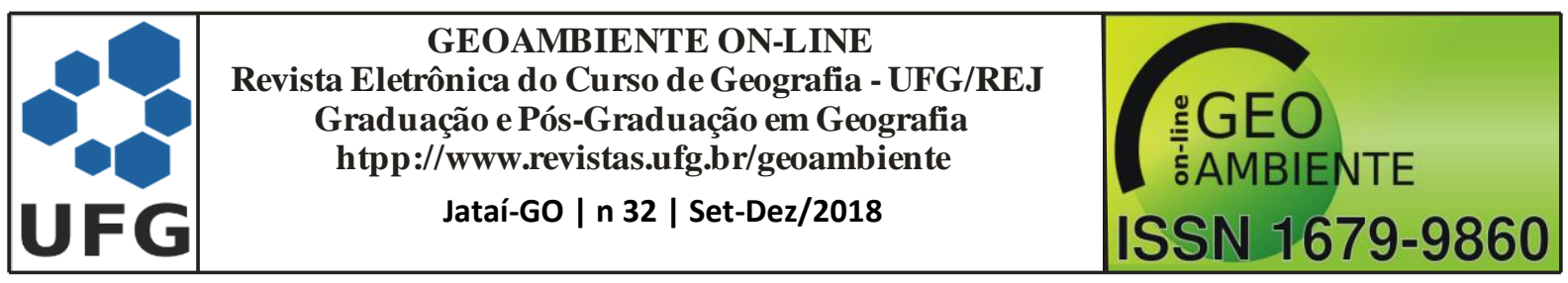

pecuária, agricultura de subsistência, extração de lenha como matriz energética, extração de solos para construção civil e mineração associada a exploração de scheelita, ouro e pegmatitos. No entanto, o manejo da caatinga, bem como, na exploração dos solos e nas atividades pecuaristas precisa ser realizado com extrema urgência, pois essas atividades são potencialmente degradadoras do solo, e os solos do município já manifestam sinais avançados de degradação.

Outro potencial do município de Currais Novos é o turismo de aventura. Esta atividade, ainda pouco explorada, renderia para o município a oportunidade de trabalhar com algo cujo potencial de degradação é inferior àqueles que vêm ocorrendo.

Outro ponto importante a ser destacado é ocorrência de espaços potenciais para conservação como o caso do Vale dos Apertados e do Pico do Totoró. Essas áreas ostentam potencial cênico paisagístico, além de rica biodiversidade, associadas a espécies endêmicas da Caatinga.

\section{Referências bibliográficas}

ANGELIM, L.A.A., MEDEIROS, V.C., NESI, J.R. 2006. Programa Geologia do Brasil PGB. Projeto Geologia e Recursos Minerais do Estado do Rio Grande do Norte. Mapa geológico do Estado do Rio Grande do Norte. Escala. 1:500.000. Recife: CPRM/FAPERN, 2006.

BERTRAND, George. Paysage et géographie phisique globale. Revue Géographique des Pyrénées et du Sud-Ouest, Toulouse, v. 39, n. 3, p. 249-272. 1968. (Paisagem e geografia física global - esboço metodológico. Tradução de O. Cruz. Cadernos de Ciências da Terra. Publicado no Brasil no Caderno de Ciências da Terra. Instituto de Geografia da Universidade de São Paulo, n. 13, 1972).

CESTARO, L. A.; ARAÚJO, P. C.; MEDEIROS, C. N.; CiSNEIROS, R. ; ARAUJO, L. P. Proposta de um sistema de unidades geoambientais para o Rio Grande do Norte. In: SIMPÓSIO BRASILEIRO DE GEOGRAFIA FÍSICA APLICADA, 12., 2007, Natal-RN. Anais. Natal-RN: UFRN, 2007. p. 267.

MENEZES, M. R. F. Estudo sedimentológico e o contexto estrutural da Formação Serra do Martins nos Platôs de Portalegre, Martins e Santana/RN. Dissertação (Mestrado). Mestrado 


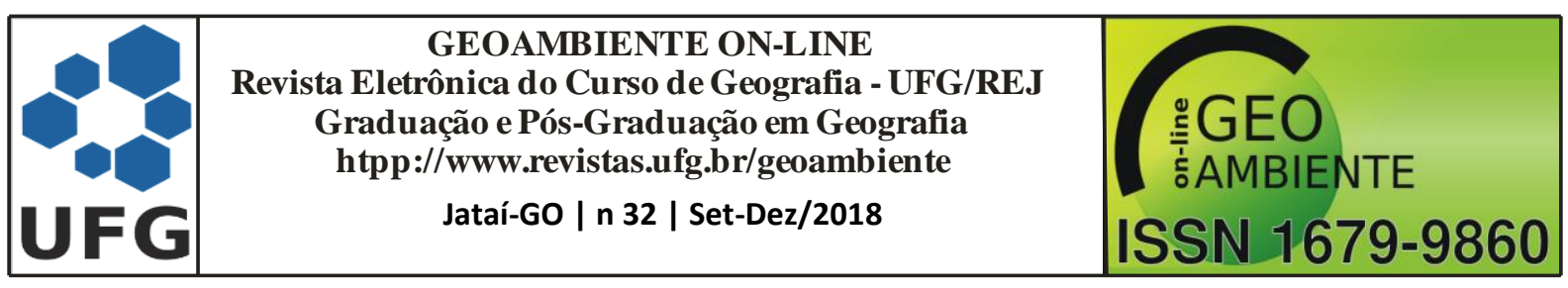

em Geodinâmica e Geofísica. Universidade Federal do Rio Grande do Norte - Natal/RN, 2009.

MONTEIRO, C. A. de F. Geossistema: a história de uma procura. São Paulo: Contexto, 2000 .

PASSOS, M. M. dos. Biogeografia e Paisagem. Presidente Prudente: edição do autor, 1988.

PENTEADO, M. M. Fundamentos de Geomorfologia. Rio de Janeiro, IBGE, 1974.

ROSS, J. L. S. Ecogeografia do Brasil: subsídios para o Planejamento Ambiental. São Paulo:

Oficina de textos, 2006.

SANTOS, M. SOUZA, M. A. A. SILVEIRA, M. L. (Orgs.) Território: globalização e fragmentação. São Paulo: Editora HUCITEC; Associação Nacional de Pós-Graduação e Pesquisa em Planejamento Urbano e Regional, 1998.

SANTOS, R. F. dos. Planejamento ambiental: teoria e prática. São Paulo: Oficina de Textos, 2004.

TRICART, J. Ecodinâmica. Rio de Janeiro. IBGE, Diretoria Técnica, SUPREN, 1977.

TROPPMAIR, H. GALINA, M. H. Ecossistemas. Mercator - Revista de Geografia da UFC, ano 05, número 10, 2006. 